\title{
Tradición católica y ritual festivo: secularización y metamorfosis de lo sagrado
}

Catholic tradition and festive ritual: secularization and metamorphosis of the sacred

Pedro García Pilán

Universitat de València

\section{RESUMEN}

El objetivo del artículo es analizar la relación entre tradición, ritual y proceso de secularización en la modernidad avanzada, a partir de un análisis histórico y etnográfico de las fiestas católicas de Corpus Christi y Semana Santa, además de algunas grandes celebraciones locales. Se defiende que la tradición moderna no es una mera herencia del pasado, sino producto de un proceso de retradicionalización selectiva de prácticas formadas conflictivamente en el mundo católico durante el período de la Contrarreforma, tras un proceso de negociación (basado en un desigual equilibrio de poder) entre hierocracia eclesial y prácticas locales comunes. En la sociedad postradicional, caracterizada por la desinstitucionalización de la religión católica, la tradición solo es posible desvinculada de cualquier dogma de fe o noción formular de verdad, y se liga exclusivamente a un ritual abierto y politeísta. De manera paradójica, la tradición moderna, rescatada de un mundo sacralizado ya desparecido, se alimenta del proceso de secularización.

PALABRAS CLAVE: secularización, tradición, ritual, Contrarreforma, politeísmo 


\begin{abstract}
The aim of the article is to analyze the relationship between tradition, ritual and the secularization process in advanced modernity, based on a historical and ethnographic analysis of the Catholic festivals of Corpus Christi and Holy Week, as well as some great local celebrations. It is argued that modern tradition is not a mere inheritance from the past, but rather the product of a process of selective retraditionalization of conflictively practices formed in the Catholic world during the Counter-Reformation period, product of a negotiation process (based on an unequal balance of power) between ecclesial hierocracy and common local practices. In post-traditional society, characterized by the deinstitutionalization of the Catholic religion, the tradition is only possible detached from any dogma of faith or formulaic notion of truth, and is linked exclusively to an open and polytheistic ritual. Paradoxically, the modern tradition, rescued from a sacred world that has already disappeared, feeds on the process of secularization.
\end{abstract}

KEY WORDS: secularization, tradition, ritual, Counter-Reformation, polytheism

Avanzada la tarde de cada Jueves Santo, en la localidad riojana de San Vicente de la Sonsierra, al finalizar la misa se inicia la Procesión de la Santa Cena. Durante la misma, y en recuerdo de la Pasión de Cristo, un grupo de penitentes, con el rostro cubierto y la espalda desnuda, se disciplina golpeándose con una madeja de lino trenzado. Ante el aviso del hermano acompañante, un "práctico" llevará a cabo la "pica" que, en recuerdo de los doce apóstoles que acompañaron a Jesucristo, aliviará los hematomas mediante la aplicación de doce pinchazos con una bola de cera provista de puntas de vidrio. La escena se repetirá, con distintos penitentes, esa misma noche y durante el Via Crucis y la procesión del Santo Entierro, que se celebran al día siguiente.

Los picaos, como se conoce a los disciplinantes de la pequeña localidad donde tiene lugar el ritual, tienen una larga historia: su Cofradía de la Vera Cruz se remonta, como mínimo, a 1551. La misma línea de continuidad con el pasado se aprecia si tenemos en cuenta quién puede salir en la procesión: cuando, no hace muchos años, unos estudiantes de confesión protestante, fascinados con el espectáculo, insinuaron a la cofradía que les gustaría flagelarse, su propuesta fue recibida con sorna: "¡Pero hombre! Para poder disciplinarse hay que ser buen católico y tener una carta de recomendación del párroco", asegura Vandermeerch (2004: 37) que fue la respuesta obtenida. 
$\mathrm{Si}$ atendemos al control doctrinal y eclesial, a la fuerte carga emocional de las escenas, cuya crudeza evoca tiempos pasados, a los atuendos de los protagonistas principales (siempre hombres), o al propio escenario, que conserva visiblemente la herencia medieval (la cofradía tiene su sede en una iglesia gótica), nos parecerá evidente que nos situamos en el terreno de la tradición. Así se lo aseguraron los protagonistas a uno de los primeros investigadores que se acercaron por la población a intentar comprender esta fiesta (Vandermeerch 2004), y así podemos corroborar fácilmente a través de internet:

En una sociedad donde predomina lo materialista, lo profano y lo lúdico, que aún se mantenga este ancestral rito penitencial, puede parecer difícil de entender, pero los 'Sonserranos', que vivimos esta tradición, generación tras generación, nos sentimos orgullosos de conservarla y reivindicamos el respeto que una tradición tan antigua se merece y el derecho a perpetuar el legado de nuestros antepasados. ${ }^{1}$

Teniendo en cuenta que prácticas como la flagelación pública son hoy sumamente marginales, podemos suponer que nos encontramos ante un reducido nicho de tradición local, un residuo propio de una población pequeña e históricamente aislada. Lo mismo sucedería con prácticas como los empalaos que se ven en Valverde de la Vera (Cáceres) o Jerez de los Caballeros (Badajoz), que constituirían "claros ejemplos de la pervivencia de una mentalidad que lleva al hombre de hoy a comportarse religiosamente exactamente igual que lo hiciera en los siglos XVI, XVII o XVIII" (Iglesias 2016: 31). Pero también podemos pensar que nos encontramos ante casos extremos de continuidad con un pasado que, en realidad, sería extensible a otros muchos lugares: se ha afirmado que las multitudinarias procesiones que jalonan gran parte del territorio español durante Semana Santa se deben a que "la fuerza de la tradición cultural resulta tan ineludible como la fuerza de la gravedad"; además, su auge permitiría concluir que "la secularización tiene sus límites" (Miguel 2006: 53, 69).

A similares conclusiones podríamos llegar si nos fijamos en los estallidos de religiosidad que se producen en múltiples celebraciones locales de matriz explícitamente católica, como la del compostelano Apóstol Santiago, la Virgen del Pilar en Zaragoza o la Romería del Rocío en Huelva, por citar solo algunos casos. El dictamen lanzado en 1938 por Hocart seguiría pues siendo válido: "Europa está tan sujeta a la tradición hoy como en otros tiempos" (1985: 164); unos años después, Shils (1975), hacía de ésta un principio normativo regulador

\footnotetext{
${ }^{1}$ https://www.nuestrasfiestas.com/la-rioja/los-picaos-en-san-vicente-de-la-sonsierra/
} 
de cualquier sociedad. Si tenemos en cuenta que las fiestas son una específica modalidad de acción ritual, estas posturas vendrían todavía apuntaladas por otros clásicos, como Mauss, quien en 1909 definió el rito como una "acción tradicional eficaz" (1970: 139), o Durkheim, que identificó su eficacia coercitiva con la de la tradición (1993: 585). Esta constituiría, pues, la clave para entender el funcionamiento del ritual.

Ahora bien, estos planteamientos presentan distintos problemas. En primer lugar, la respuesta de la tradición es de por sí sola insuficiente, pues no serviría para explicar, por ejemplo, porqué las antaño extendidísimas celebraciones de la Virgen del Rosario han desaparecido o han quedado reducidas a un papel residual; o porqué en la actualidad la Semana Santa cuenta con muchos más cofrades y suscita más interés que el Corpus Christi. Por otra parte, si partimos de la definición weberiana de la tradición como un "actuar consensual" heredado irreflexivamente de los antepasados (Weber 2002: 264), no parece evidente que las reflexivas sociedades de nuestra modernidad avanzada puedan ser definidas como tradicionales. Así, las tesis aludidas chocarían en el marco teórico de la “destradicionalización” de Beck (1998), o de Giddens (1997), quien, al definir a nuestra sociedad como "postradicional", establece una nítida distinción entre la tradición antes y después de la modernidad. En las sociedades tradicionales, la tradición sirve para organizar la memoria colectiva, tiene un carácter vinculante, está custodiada por guardianes e implica el ritual, siendo éste un mecanismo que garantiza la preservación de aquélla. Basada en una "noción formular de verdad", la tradición ofrece a la comunidad un alto grado de seguridad ontológica, a la vez que prescribe castigos a la conducta desviada. En la modernidad avanzada, el "ritualismo" queda vinculado a la verdad formular: "el ritualismo, y, por consiguiente, la tradición, siguen existiendo siempre que la verdad formuliaca constituya una forma de construir interpretaciones del tiempo pasado" (Giddens 1997: 132), lo que dejaría a la tradición un papel residual. Pero esto nos aboca a un nuevo problema: si ritual y verdad formular se mantienen indisolublemente relacionadas, habrá que concluir que los rituales sobreviven hoy como meros residuos del pasado, algo que, pese a la clasificación de Alexander (2017) de nuestras sociedades como "posrituales", la revitalización festiva acaecida desde las últimas décadas del siglo XX desmiente a todas luces (Boissevain 1992). Aquí cabe decir que Giddens no incide lo suficiente en el proceso de secularización. Y este se revela crucial pues, en sociedades tradicionales, la tradición remite a una realidad sagrada, de carácter trascendente (Ariño 1999), lo que cobra especial relevancia si tenemos en cuenta que siempre hay un vínculo entre el ritual y lo sagrado (Maissonneuve 1991). 
Parece necesario, pues, analizar la relación entre ritual festivo, tradición y proceso de secularización. Se defenderá aquí que, lo que en condiciones de modernidad avanzada entendemos por tradición, es el resultado de un proceso en dos largas fases: la primera consiste en un programa de sacralización fuerte que, más allá de la indefinición temporal que suele tener en sociología la referencia a prácticas tradicionales, tiene su principal punto de anclaje en el mundo católico a partir del Concilio de Trento (1545-1563), alcanzando su punto álgido en el siglo XVII y durante la primera mitad del XVIII. En la segunda fase, y de manera paradójica, la tradición se construirá como un dispositivo producto del proceso de secularización, y en la modernidad avanzada su práctica contribuirá a profundizarlo. Teniendo en cuenta la polisemia que el término "secularización" ha suscitado en sociología durante las últimas décadas (Gil Gimeno 2017), se entenderá aquí por secularización básicamente un fenómeno de desinstitucionalización e individualización religiosa.

Se analizarán, desde una perspectiva de larga duración, los grandes rituales festivos del calendario católico que tienen en las procesiones su manifestación más visible: las celebraciones de Semana Santa y Corpus Christi, sin perder de vista algunas celebraciones de carácter más estrictamente local. El análisis se dividirá en dos partes: en la primera, basada en fuentes secundarias, se analizará la escalada organizativa que se produce en la organización del ritual entre los siglos XIV y XVIII, así como los principales significados que toman las formas de dramatización formadas durante dicho período. En la segunda, basada en el trabajo de campo realizado mediante entrevistas y observación participante parte del cual ha sido utilizado anteriormente (García Pilán 2010, 2020)-, así como en material etnográfico obtenido en internet, ${ }^{2}$ nos centraremos en las transformaciones modernas del sujeto celebrante y el objeto celebrado.

\section{INSTITUCIONALIZACIÓN: COFRADÍAS Y SACRALIZACIÓN}

Ningún ritual con un cierto grado de complejidad puede producirse sin algún tipo de organización, basándose esta con frecuencia en la actualidad en asociaciones formales voluntarias (Ariño 1993b). En los rituales que aquí trataremos, tales organizaciones son principalmente cofradías (o hermandades), un tipo de organización surgida en la Edad Media y que se desarrolla ampliamente durante la Edad Moderna. Hoy, son numerosas las cofradías que se

\footnotetext{
${ }_{2}$ Para los picaos de San Vicente de la Sonsierra son de utilidad las entrevistas que pueden verse en https://www.youtube.com/user/CulturadeRioja/videos
} 
legitiman recurriendo a un pasado "ancestral": por ejemplo, entre las de Semana Santa no son pocas las que remontan su genealogía hasta su fundación por San Vicente Ferrer, y es común que, a la hora de buscar los orígenes de las celebraciones de Semana Santa, se aluda al fenómeno medieval de los flagelantes. Se partirá pues de estos.

La celebración de la Semana Santa se ciñó durante siglos al interior de los templos, y las primeras procesiones no aparecieron hasta los siglos XIV y XV, cuando, durante la noche del Jueves a Viernes Santo, aparecen desfiles de flagelantes prolongando, fuera del templo, lo que se había celebrado en su interior (Ladero 2015: 54; Narbona 2017: 160-161; Sánchez Herrero 1995). Pero hay que matizar que esta vinculación a los días de Pasión es un intento eclesiástico de controlar una práctica previa, pues los flagelantes no nacen, ni mucho menos, para celebrar la Semana Santa, sino que son una figura característica de la agitación religiosa bajomedieval que había hecho su irrupción en la Italia del siglo XIII, y que no deja de ser vista con suspicacia por la jerarquía eclesiástica, pues los laicos que llevan a cabo en público esa imitatio Christi colectiva que suponía ensangrentar en público el propio cuerpo, se consideran a sí mismos portadores de una misión redentora para toda la humanidad. Estamos todavía lejos de lo que conocemos como cofradías tradicionales: son grupos itinerantes, que recorren el territorio con la intención de purificar con su sufriente ejemplo a una comunidad a la que conmocionan. En Alemania toman un carácter decididamente antieclesial, lo que, junto al alto nivel de formalización que toma el movimiento, hace del mismo una herejía de tintes revolucionarios (Cohn 1985: 126-161). Pero aun en los casos en los que no hay un claro desafío doctrinal, la iniciativa de tales grupos, que actúan con plena autonomía, no dejará de inquietar al alto clero, provocando tanto debates teológicos como medidas para controlar el movimiento (Vandermeersch 2004: 99-137). Desde este punto de vista, las nutridas compañías de flagelantes que acompañaron a predicadores como San Vicente Ferrer por numerosas ciudades europeas durante los siglos XIV y XV, pueden ser vistas como un incipiente intento de control de prácticas heterodoxas, no exento de polémicas (Daileader 2019: 135-169) y dirigido por un líder carismático. En todo caso, el objetivo de estas compañías está todavía muy lejos de ceñirse a la organización de una fiesta: buscan, a través del ejemplo y la contrición, conseguir una reforma moral de la sociedad.

Aunque hay precedentes medievales, es en el siglo XVI cuando se inicia una reconducción efectiva del fenómeno: en 1536, el Papa Paulo III intenta regular la penitencia, concediendo indulgencias a las cofradías que cumplan determinados 
requisitos (Sánchez Herrero 1995: 22-23). En un proceso de pacificación social y rutinización del carisma, esos flagelantes que causan frecuentes problemas de orden público son sustituidos por asociaciones formales, sujetas a la legislación canónica y fijadas a un territorio: asistimos así al inicio de un proceso de institucionalización que merece ser visto como un episodio de esa específica racionalidad histórica de la Iglesia católica que analizase Weber. El carácter en ocasiones cerrado, casi sectario que predomina en algunas de estas asociaciones (Vandermeersch 2004: 105), es anulado y sustituido por organizaciones que buscan encuadrar a amplios sectores de la población; así, lo extraordinario se vuelve ordinario, reintegrándose en la realidad cotidiana. Estamos, pues, ante un intento de control centralizado que pretende normalizar y homogenizar prácticas heterogéneas, y que significativamente se produce a comienzos de la Edad Moderna: como advirtiese Delumeau, "a partir del siglo XVI, poder eclesiástico y poder civil se apoyaron con fuerza uno sobre otro para vigilar mejor la conducta religiosa y moral de sus poblaciones" (1989: 628).

Lo dicho no significa que no hubiese cofradías en la Edad Media: son centenares las que tenemos localizadas en las ciudades hispanas. Pero el rasgo más destacable es su vinculación a gremios, que tenían sus propias advocaciones (Navarro 2014). Durante mucho tiempo serán asociaciones propias de un estadio civilizatorio en el que el equilibro de relaciones entre el "yo" y el "nosotros" (Elias 2000) se inclina claramente del lado de los segundos: sus funciones son esencialmente comunitarias, tanto desde el punto de vista espiritual como desde el económico (Lozano y Torremocha 2013); es decir, cumplen funciones asistenciales propias de una sociedad sacralizada y escasamente estatalizada, que abarcan desde acompañar a los cofrades en su muerte y entierro hasta dar soporte económico a sus viudas, apoyo a enfermos en hospitales, etc.; rasgos que, en general, perdurarán hasta el siglo XVIII. Tal continuidad funcional no debe hacernos pensar que eran algo estático: se ha establecido una nítida distinción entre las cofradías medievales y las surgidas después del Concilio de Trento: las primeras, articulando lazos de solidaridad familiar y vecinal, habrían proporcionado una respuesta alternativa a la Iglesia al problema de la salvación; no en vano, Bossy (1998) ha hablado de un "católico colectivo" para este período. Por el contrario, las segundas "constituyeron uno de los medios de la Iglesia oficial para homogeneizar las devociones y aculturar en materia de fe a las masas urbanas, primeramente, y campesinas, en segundo término" (Mantecón 1990: 27). Tal como las conocemos hoy, las cofradías son pues un fenómeno que arranca del siglo XVI, y que se fortalece y multiplica exponencialmente a partir del Concilio de Trento, es decir, durante el período de confesionalización y 
despliegue masivo de disciplina social iniciado durante la Contrarreforma o "renovación católica" (Prodi 2017; Po-Chia Hsia 2007). Asistimos entonces un proceso de institucionalización de la Iglesia Católica sin precedentes.

Asentadas en conventos y parroquias, las cofradías serán piezas fundamentales del nuevo modelo de "civilización parroquial" que, reestructurando, ampliando y densificando la red parroquial medieval, articula una sacralidad ligada de manera específica al territorio (Restif 2006). Este se resignifica a través del reforzamiento de la presencia simbólica de la Iglesia, mediante una semantización permanente; la señalización del camino por el que deben transcurrir los Via Crucis en Semana Santa es un perfecto ejemplo de ello: su propósito será constituir a la procesión que transcurrirá por el mismo en un instrumento de pretendida armonía social (Rico, 2006). Al acotar y estabilizar el espacio, se le imprime un nuevo carácter: como indicase Halbwachs (2004: 145-161), las parroquias y la topografía religiosa vinculada a las mismas han actuado históricamente como un factor esencial para el mantenimiento de la memoria del grupo, contribuyendo a destacar esa sensación de eternidad del hecho religioso sin la que es imposible construir una tradición. Se disciplina así el espacio, pero también el tiempo: constituidas bajo múltiples advocaciones, las cofradías articulan un calendario ritual que sirve de base a la construcción de tal memoria. Al vincular la religión de manera estrecha a un espacio local, también se pondrán, a largo plazo, las bases de una dualidad sagrada: la que corresponde a lo divino-trascendente, y la que, con el tiempo, acabará sacralizando las identidades locales; será en este nivel territorial donde arraiguen lo que, en relación con la "gran tradición" eclesiástica, Burke (1996) denomine esas "pequeñas tradiciones", que se reparten por toda Europa entre los siglos XVI y XVIII, y que se corresponden con lo que Thompson (2000) llamó "costumbres comunes" y Christian (1991) formas de "religiosidad local". Aquí, teniendo en cuenta que los grupos populares o plebeyos no tienen constancia de estar defendiendo ninguna "tradición" en las sociedades llamadas tradicionales, sino que legitiman determinadas prácticas aludiendo a "costumbres" (Thompson 2000: 18-20), se hablará en los sucesivo de costumbres locales comunes.

Estas cofradías responden al modelo estratificado de sociedad estamental: las hay abiertas y cerradas, de carácter nobiliario, de oficios, étnicas, etc. Podemos distinguir entre las ya citadas cofradías gremiales, asistenciales, devocionales y penitenciales (Arias y López-Guadalupe 2017). Si las primeras fueron las más extendidas durante el período bajomedieval, la primacía corresponde ahora a las devocionales (todavía no a las penitenciales o de Semana Santa), que incluyen de advocaciones marianas, de santos, sacramentales y de ánimas. Estas responden de manera destacada a criterios teológicos en la movilización contra el 
protestantismo: las dedicadas al Santísimo Sacramento ritualizarán el misterio de la transubstanciación, mientras que las de ánimas responden a la creencia en el purgatorio. Todas las parroquias debían tener, como mínimo, una cofradía dedicada a estas devociones, estando además sumamente extendidas las del Rosario.

Pese a que ya han alcanzado un elevado grado de especialización, en la base de todas ellas está la práctica de esa virtud teologal del catolicismo que es la caridad, y los vínculos de solidaridad dentro de la cofradía son tales que llegan a incluir a los difuntos (Sánchez de Madariaga 1999; 24-26). Pese a su carácter corporativo, su simbolismo es compartido por el conjunto de la sociedad, lo que amplía sus funciones comunitarias. Proporcionan, pues, un marco de referencia estable en una sociedad acuciada por el miedo y necesitada de encontrar una cierta seguridad en una fuerte solidaridad grupal, regulada desde criterios de jerarquización social (Candau 2020: 321). Actúan frecuentemente de manera coactiva: la obligatoriedad de participar en el culto o cumplir con determinadas prácticas de asistencia y apoyo a los hermanos está ampliamente documentada (García Fernández 2009); en Cantabria se prescriben penalizaciones para los cofrades que no acudan a las celebraciones de Semana Santa, mientras que, en Sevilla, en 1570, los hermanos del Gran Poder se comprometen a permanecer dentro de la cofradía toda su vida (Mantecón 1990: 31; Candau 2020: 324-325).

Las cofradías se constituyen pues como agentes fundamentales para llevar adelante un vasto proyecto de reforma moral y de las costumbres. Como tales, son susceptibles de ser interpretadas como instrumentos de la "cultura oficial hegemónica" que se despliega tras Trento (Mantecón 1990: 22-23). Su función es, así, disciplinar a un hombre nuevo, no conflictivo e integrado en el ritual a través de la su hermandad. El modelo ideológico del cofrade es monástico: para sus promotores (principalmente frailes mendicantes) las cofradías ofrecen a los seglares la posibilidad de acogerse a una regla, orientando las conductas hacia la salvación, la caridad al prójimo y la armonía social, contribuyendo así a la pacificación del vecindario. La evolución de la práctica de la flagelación sirve como indicador de una tendencia: no solo se acotará cada vez más en el espacio y en el tiempo, ciñéndola a celebraciones concretas (cada vez más a la Semana Santa), sino que la cofradía controlará la práctica de la penitencia pública, asumiendo casi el monopolio legítimo de la misma. ${ }^{3}$

${ }^{3}$ La práctica conventual de la flagelación seguirá caminos distintos (Vandermeerch 2004). 
No se pretende afirmar que las cofradías del Antiguo Régimen se reduzcan a dóciles instrumentos de la Iglesia: su práctica se desvía constantemente de las directrices oficiales. Son así "entes híbridos", mediadores entre la cultura hegemónica y la plebeya (Mantecón 1990: 22.23). Se constituyen como agentes importantes de negociación con la Iglesia, lo que provoca también un protagonismo en el mantenimiento y evolución de múltiples prácticas locales que esta, atendiendo a sus principios universalizadores, hubiera preferido erradicar: señala Giddens que "las 'grandes tradiciones' estaban asociadas, sobre todo, con la racionalización de la religión", pero su poder sobre la comunidad local nunca será completo, pues frecuentemente esta opondrá filtros a sistemas más racionalizados, obligando a la tradición escritural a recontextualizarse localmente (1997: 118-119). Las costumbres comunes locales son pues, en gran medida, producto de la acción y mediación de estas cofradías que, en todo caso, son piezas fundamentales en la sistematización del calendario ritual católico, encuadrando una disciplina corporal que comenzará a basarse más en el orden y en el lenguaje militar (Rico 2006).

$\mathrm{Al}$ abordar la dramatización del ritual comprobamos que, también aquí, y pese a los continuos cambios acaecidos durante los períodos anteriores, el Concilio de Trento marca un punto de inflexión. Se produce una multiplicación de celebraciones litúrgicas, procesiones y romerías que jalonan el calendario festivo anual. Así, comparadas con sus precedentes medievales, las procesiones del Barroco, articuladas por las florecientes asociaciones de fieles, muestran un carácter más moderno, que tiene un claro contenido político, pues a través de las celebraciones públicas contrarreformistas se configuran nuevos espacios de manifestación del absolutismo monárquico (Rico 2006).

Esto se hace patente durante las celebraciones de la Pasión: en correspondencia con lo que hemos visto sobre las cofradías, "hasta muy avanzado el siglo XV prácticamente hasta el siglo XVI- no hay procesiones de Semana Santa en el sentido en que las contemplaremos posteriormente" (Fernández Basurte 1998: 40). Cierto es que, dentro del año litúrgico, la Semana Santa juega un papel histórico central: dentro del ciclo soteriológico, la Pasión de Cristo supone la culminación del tiempo orientado hacia la Pascua, por lo que, durante la mayor parte de la historia cristiana, la Semana Santa fue "el momento más importante del año" (Muir 2001: 70). Tiempo de dolor, de dramática teatralización de la sangre y el sufrimiento, la exaltación colectiva de fervor alcanzaba su paroxismo durante estos días (Cardini 1984: 144-150), que adquieren sin embargo ahora un nuevo y decisivo impulso, pudiéndose hablar de un "modelo barroco de Semana Santa" (Fernández Basurte 1998). Al tratarse de una procesión nueva, sin un 
arraigo previo, será vista por la hierocracia como un instrumento de adoctrinamiento popular (Fernández de Paz 1999). Así, se ha hablado de un "síndrome de la batalla" en el que las procesiones de Semana Santa acompañan al cuerpo muerto de Cristo como si de un gran jefe militar se tratara (Fernández Basurte 1998: 294-305). Esto no significa, ni mucho menos, que las procesiones hayan abandonado su carácter truculento: Maravall (2002: 356-358) habló de una "pedagogía de los sentimientos de violencia", que no deja de ser clave en el desarrollo del ritual, y la flagelación (llamada ahora significativamente "disciplina") seguirá siendo un fenómeno penitencial característico del Barroco (Rodríguez Mateos, 1989). Pero su encauzamiento se produce con una voluntad de control y con unos efectos civilizadores, en el sentido eliasiano del término, que se hace evidente si comparamos las nuevas prácticas, sancionadas por el clero y organizadas por cofradías, con recorridos claramente determinados, con las largas itinerancias flagelantes de los siglos anteriores, que duraban hasta treinta y tres días ininterrumpidos -uno por cada año vivido por Cristo en la tierra- y transcurrían de ciudad en ciudad (Cohn 1985: 132). Se produce una depuración de prácticas susceptibles de resultar heterodoxas, que está en la base de la represión de representaciones paralitúrgicas teatralizadas de la Pasión, de orígenes medievales, que son ahora sustituidas por los pasos escultóricos o "de Misterio" (Bernales 1999: 83). Este punto es importante, pues, frente a los excesos en que incurren actores disfrazados de figuras sacras, la imagen exenta o el paso teatralizado cumplen unos requisitos establecidos estética y doctrinalmente. La Contrarreforma convierte el arte en un instrumento privilegiado de propaganda del catolicismo, destinado a estimular la devoción y encauzar la penitencia, desplegándose una política de imágenes al servicio del ritual que servirá tanto para mover a devoción como para articular comunidades políticas de distinto nivel en torno a ellas (Alonso Ponga y Panero García 2008; Orozco 2009; Marinas 2012).

Evidentemente, son numerosas las prácticas locales que el clero no podrá erradicar completamente: así, en lugares pequeños, numerosas y reiteradas prohibiciones eclesiásticas, como las referidas a representaciones de la Pasión con actores o a los excesos de la penitencia (que hacen perder al Estado el control sobre el cuerpo de los súbditos), tendrán más dificultades para imponerse. Incluso el éxito de la imagen escultórica será en parte producto de una negociación, ya que el deseo de humanizar a determinadas imágenes acabará dando lugar a un modelo procesional característico, como es el caso andaluz (Fernández de Paz 1999). Habrá siempre pues prácticas locales que habrá que aceptar, en un equilibrio diferencial de poder en el que la Iglesia siempre tendrá 
de su parte más fuerza para imponer una ortodoxia que muchas veces no será, sin embargo, suficiente más que para corregir lo inasumible. Al respecto, cabe tener muy en cuenta las consideraciones de Christian, para quien la práctica histórica de catolicismo "es un proceso constante de creación de formas comunes, más allá de los límites locales y nacionales (...) y una continua adaptación y apropiación de los agentes y devociones generales para fines locales" (1991: 216-217).

Pero es Corpus Christi la que se constituye como fiesta del Antiguo Régimen por excelencia. Sus precedentes son medievales y ya entonces se aprecia una cierta lógica centralizadora: nacida en Lieja como una devoción local, la fiesta se expande, en lucha contra las herejías eucarísticas, por las ciudades europeas durante los siglos XIII y XIV, convirtiéndose rápidamente en una devoción multitudinaria, lo que va ligado a su desarrollo procesional. Con distinto ritmo, los gobiernos municipales se van implicando en la organización de la fiesta, que además se centraliza en una única procesión para toda la ciudad (empezó a nivel parroquial). A la procesión se le van añadiendo elementos que aumentan la espectacularidad de un ritual que se convierte en un símbolo competitivo entre ciudades. Autoridades civiles y religiosas se coordinan para construir "una ruta sacra y política, empleada para casi todos los ceremoniales de la ciudad" (Narbona 2017: 169). Con todo, el nivel de jerarquización social que establece la fiesta medieval dista del esplendor que alcanzará durante la Edad Moderna: será tras el Concilio de Trento cuando adquiera el carácter de fiesta del "triunfo católico" (Ariño 1988: 369). Los desfiles sacralizan un orden social al que representan y enaltecen, produciéndose una identificación entre Cristo como rey supremo y el monarca absoluto, bajo la legitimación de la apoteósica exhibición de la Eucaristía. Se trata, ante todo, de jerarquía, pero es mucho más que eso: absorbe elementos de la cultura popular, convirtiéndose así en una fiesta alegre, con un alto nivel de consenso (Ariño 1988: 405).

No solo Corpus y Semana Santa experimentan un punto de inflexión tras Trento: numerosas fiestas locales, de tipo patronal o mariano, experimentan ahora una notable consolidación, no exenta de significativos cambios. Un ejemplo nos lo proporciona la zaragozana Virgen del Pilar: durante la Edad Media tuvo un papel sumamente discreto, habiendo tenido que atravesar un proceso de dura competencia por un espacio simbólico dominado por otras devociones. Su hegemonía no comenzará hasta el siglo XVII, cuando -en consonancia con esas "claves mágicas" que integran la religiosidad barroca (Sánchez Lora 1989)-, tras mostrar la eficacia de sus poderes taumatúrgicos en momentos de emergencia como epidemias de peste, la imagen pase a ocupar el "centro simbólico de la ciudad", erigiéndose en su patrona en 1653 (Ramon Solans 2014: 56-57). Algo 
similar ocurre con la Virgen de los Desamparados de Valencia: en el siglo XV, la cofradía que custodiaba la imagen se dedicaba a la asistencia de menesterosos de diverso tipo, pero su devoción se extiende durante los siglos XVI y XVII, siendo utilizada por toda la ciudad en momentos de calamidad, celebración militar, etc., asumiendo un claro carácter cívico a partir de 1622, que pasa por un proceso de "magnificación" en el XVIII (Pingarrón 2017). En la isla canaria de El Hierro, el culto a la Virgen de los Reyes, llegada de manera milagrosa a la isla a principios del siglo XVI, comienza como un culto de pastores para, tras frecuentes sequías y plagas de langosta, desplazar al patrono insular, San Sebastián, a principios del siglo XVII, imponiéndose en 1745 la cuatrienal "Bajada" que constituye la gran fiesta de la isla en la actualidad (Galván 1997). Podrían multiplicarse los ejemplos.

Cuaja así, a partir de la segunda mitad del siglo XVI y hasta el XVIII, una religiosidad con objetivos moralizadores y tan acorde al modelo de religiosidad tridentina como a los principios de absolutismo monárquico. Tal religiosidad se expresa mediante un denso calendario ritual festivo, que solo se ha tratado aquí muy parcialmente. Todo ello configura un modelo social que responde en buena parte a lo propuesto por Giddens: se asienta en un territorio parroquialconventual que garantiza la pervivencia de la memoria de la comunidad, tiene un carácter vinculante, está custodiada por guardianes con capacidad sancionadora e implica como instancia imprescindible unos rituales que exponen a la comunidad una verdad formular custodiada por una hierocracia con capacidad sancionadora. Es cierto que esa autoridad se ve contestada frecuentemente, pero el conflicto se produce dentro de un campo de fuerzas y significados en el que la ortodoxia está en manos de los clérigos y, además, los agentes plebeyos que, inspirándonos en Bourdieu (2000), pudieran ser definidos como "herejes del campo", carecen de capacidad para proponer alternativas que rompan la cosmovisión hegemónica. Pese a la importancia de las prácticas locales, la unidad mítico-ritual del universo católico permanece inalterada. A esa configuración se ha llegado a través de un conflictivo proceso de racionalidad coactiva desplegada con la finalidad de subordinar todos los aspectos de la vida terrena a lo trascendente.

\section{DESINSTITUCIONALIZACIÓN: SECULARIZACIÓN Y POLITEÍSMO}

Se tratarán en esta segunda parte algunos cambios inducidos por la modernidad en los grandes rituales festivos heredado del Antiguo Régimen cuya formación hemos visto hasta ahora. Se abordarán tanto las más significativas 
transformaciones en el sujeto celebrante como en el sujeto celebrado, centrándonos en tres puntos: las cofradías y la religiosidad cofrade, la evolución de los rituales hacia significados politeístas y la patrimonialización de la fiesta.

\section{COFRADÍAS Y RELIGIOSIDADES}

El margen de autonomía que han alcanzado las cofradías durante el Antiguo Régimen provoca constantes conflictos con el poder, tanto eclesiástico como político, lo que provoca la fuerte ofensiva ilustrada contra las mismas (Arias y López-Guadalupe 2002). No procede trazar aquí las vicisitudes atravesadas por estas asociaciones durante el siglo XIX (desamortización, secularización, etc.); baste apuntar que, en dicho período experimentan un notable proceso de transformación: "las viejas cofradías, reflejo de las categorías sociales tradicionales de un orden jerárquico se transformaron en simples asociaciones de individuos piadosos" (Callahan 1989: 177). Pierden pues su antiguo carácter socio-profesional y asistencial, para transformarse en cofradías de barrio de carácter estrictamente devocional.

Durante los años veinte del siglo pasado, en consonancia con el proceso general de modernización festiva que experimentan fiestas como Fallas de Valencia o Moros y Cristianos, asistimos a una vertiginosa multiplicación del número de hermandades, pero con un importante matiz: mientras numerosas asociaciones como las de Corpus Christi, de ánimas o del Rosario decaen, las hermandades de Semana Santa crecen, al tiempo que se reorganizan sobre bases más modernas. Determinadas élites económicas y culturales se integran en ellas, lo que supone una escalada burocrática: los viejos cargos son sustituidos por consejos de gobierno, con presidentes, secretarios y una moderna contabilidad. Además, surgen juntas locales de fiestas, "entidades supraasociativas", u organizaciones de segundo nivel que coordinan e integran a las asociaciones (Ariño 1993b); estamos así en los orígenes de lo que se acabará siendo el Consejo General de Hermandades y Cofradías de Sevilla, la Junta Pro Semana Santa de Zamora o la Junta Mayor de la Semana Santa Marinera de Valencia, por poner solo unos casos; es decir, órganos centrales especializados en la organización del ritual, que gozan de un elevado margen de autonomía respecto a las autoridades eclesiásticas. Se ha pasado así de la racionalidad coactiva desplegada durante el período de institucionalización católica a una racionalidad moderna, progresivamente autónoma y autorreferente.

Tal avance secularizador se trunca con el franquismo, período que no solo reorganiza gran parte de las cofradías anteriores a la Guerra Civil, sino que crea 
nuevas asociaciones religiosas, especialmente de Semana Santa, en número que en ocasiones sobrepasa a las preexistentes. Las cofradías son de nuevo consideradas con una función resacralizadora, y su cúpula está formada por personajes afectos al régimen: son las "cofradías estalactita", asociaciones integradas verticalmente, estrechamente controladas desde los poderes eclesiásticos, políticos y militares (Mancha Castro 2020: 179-197). Tras la decadencia -más acusada en unos lugares que en otros- durante los años sesenta y principios de los setenta experimentada por estas asociaciones, asistimos a una nueva fase de revitalización, durante los años ochenta y noventa del siglo XX, pero, a diferencia de momentos anteriores, ahora la iniciativa es impulsada exclusivamente desde la sociedad civil. Por todo el territorio español se fundan numerosas hermandades de Semana Santa, cuya existencia no puede atribuirse al mero mantenimiento de una tradición. Además, sus características muestran radicales cambios respecto a cualquier precedente tradicional.

Estas cofradías están coordinadas, como se ha indicado, por una entidad supraasociativa, que es la que fija ahora la ortodoxia festiva, estableciendo recompensas, imponiendo multas por infracciones, etc. Estos organismos, altamente especializados, funcionan gracias una burocracia que, en determinados casos, puede llegar a ser profesionalizada, pero que siempre conlleva una escalada burocrático-administrativa que se plasma también, a menor escala, en el ámbito de cada cofradía. La legalidad racional ha desplazado a la autoridad tradicional, y el reencantamiento del mundo se organiza ahora a través de medios genuinamente desencantados y con finalidad intramundana. Hasta tal punto llega esta transformación que, en la actualidad, sería raro encontrar una cofradía que no estuviese registrada como asociación cultural. Hay casos todavía más explícitos: la iniciativa de un pequeño grupo de amigos por revitalizar una fiesta en franca decadencia terminó originando la actual Associació d'Amics del Corpus de la Ciutat de València; en El Hierro, la cofradía encargada desde 1944 de organizar la Bajada de la Virgen de los Reyes fue reemplazada por una fundación en 1993.

Por otra parte, las cofradías tienen -al menos en localidades donde la Semana Santa es una fiesta de relieve- locales propios, que permiten un ejercicio continuo de la sociabilidad. Esto permite recrear la fiesta a escala grupal y microgrupal a lo largo de todo el año (García Pilán 2011); además, supone una escalada en la secularización de la fiesta, al sacar al ritual del ámbito parroquial como principal base operativa. La importancia otorgada al local como "punto de 
concordia"4 necesario para el funcionamiento de un ritual que, durante siglos, existió sin nada similar, muestra las profundas transformaciones en el mismo. El local se constituye como un nuevo espacio de sacralidad inmanente y difusa, parte fundamental del ritual, que nos traslada, casi a capricho, a una realidad extraordinaria (García Pilán 2006).

Las motivaciones para pertenecer a una cofradía son diversas. El análisis de las entrevistas realizadas en Valencia permite interpretar estas asociaciones desde la categoría de las "instituciones intermedias" que Berger y Luckmann (1997) postulan como necesarias entre el individuo y el macrosistema social, de cara a proveer de reservas de sentido al primero:

...hay muchas posibilidades ahí. Está pues la gente que necesita comunicarse con alguien, la gente que necesita estar con otros para poder llegar a vivir la devoción, la Semana Santa, la gente que se encuentra un poco sola y así encuentra amigos, la gente que así llena huecos de su vida... hay gente de mucho tipo. ${ }^{5}$

A partir de una base social heterogénea, esta sociabilidad cotidiana permite trascender el aislamiento y entrecruzar diversos tipos de relaciones que no responden a la lógica del mercado; pero ese "llenar huecos" tiene que ver con carencias inequívocamente modernas, y muy poco con las prácticas de las comunitarias cofradías preindustriales. Por otra parte, son muy dispares los niveles de implicación entre los directivos y la masa de cofrades, y relativamente frecuente la alternancia entre altos niveles de permanencia y casos de cofrades que, o bien abandonan antes o después la cofradía, o van saltando de una a otra (García Pilán 2010: 184-186), en contraste con los firmes compromisos que hemos visto para las cofradías barrocas. Esto nos acerca a esas "comunidades estéticas" que Bauman definió como el tipo de comunidad que perdura "mientras dure el ritual semanal o mensual programado, y vuelve a disolverse una vez reconfortados sus miembros" (2003: 85). Aquí resulta interesante retomar a Williams (2000), quien destacó el carácter selectivo de toda tradición, lo que implica una escalada reflexiva que nos sitúa en las antípodas de la herencia consensual de las sociedades orientadas a la tradición. Lo que proporciona la cofradía es un reencantamiento débil que se hace posible a través de ese mecanismo de retradicionalización selectiva de la vida cotidiana que es la

\footnotetext{
${ }^{4}$ Expresión recogida en entrevista realizada en la Hermandad del Santísimo Cristo de los Afligidos, Valencia (todas las entrevistas fueron realizadas en esta ciudad).

${ }^{5}$ Hermandad de Nuestro Padre Jesús Nazareno.
} 
sociabilidad cofrade (García Pilán 2006), y que permite alcanzar la liminalidad casi a capricho, alternado cotidianamente, si así se desea -y solo por decisión individual y revocable-, estructura con communitas (Turner 1988). La pertenencia a la cofradía puede producir sensación de fraternidad, de igualdad, de pertenencia, pero estamos muy lejos de las formas comunitarias orgánicas de las sociedades tradicionales. No hay, para la mayoría de cofrades, responsabilidades éticas ni compromisos a largo plazo; el "crepúsculo del deber" que caracteriza los códigos sociales postmodernos (Lipovetsky 2005) ha alcanzado de pleno también a estas asociaciones:

yo siempre he pensado que la persona tiene que ser lo primero, antes que la cofradía; si a mí por estar aquí a lo mejor me diera un infarto, ten por cuenta que yo no estaría, o sea que yo creo que sería, primero, primordial la persona. O sea que no... antes que todo lo demás, ¿eh? ${ }^{6}$

Desde esta abierta primacía del individuo sobre el grupo, resulta lógico que se perciban incertidumbres acerca del futuro de la tradición, ya que esta no depende tanto de una costumbre local común, transmitida intergeneracionalmente, como de la suma de voluntades individuales:

Porque la gente es muy independiente hoy en día, entonces la gente escucha los tambores y viene, pero realmente no le supone tampoco tanto ¿sabes? No le marca tanto su vida, no es tan vinculante como puede ser a mí que me vengo todos los viernes a cenar con mis amigos. Entonces la gente no la vincula tanto, y algo que no te vincula es más fácil de dejar... ${ }^{7}$

Esta situación crea la necesidad de intentar distinguir entre lo que, en Semana Santa es o no religión. El criterio para delimitar los confines entre una y otra es, precisamente, la tradición:

estamos a medio camino entre lo que es religión y lo que no es religión, y entonces a veces es muy agradable, pero a veces es muy desagradable también porque la gente mezcla lo que es tradición pura de su familia con sentimientos religiosos, que yo sin duda creo que están ${ }^{8}$.

\footnotetext{
${ }^{6}$ Hermandad del Santísimo Cristo del Salvador.

${ }^{7}$ Ibídem.

${ }^{8}$ Hermandad del Santo Cáliz.
} 
Esa división es clave porque, en el discurso cofrade, enunciar la tradición significa realmente, normalizar la secularización (García Pilán 2010). No se trata de un ámbito al margen de lo sagrado, sino un ámbito en el que lo eclesial se queda ampliamente desbordado. Tradición es devoción desinstitucionalizada a la propia imagen, pero también identidad, sociabilidad, deseo de estar con los amigos, sacralización del lazo social, desfile por la calle, communitas, en definitiva.

La transmisión familiar, clave en sociedades tradicionales, no ha desaparecido, pero sí se ha visto progresivamente desplazada por formas de reclutamiento basadas en redes amicales y, lo que es más significativo, por la incorporación masiva de individuos sin ninguna experiencia previa en el ritual. Incluso son frecuentes los casos en que los hijos se integran en la cofradía y arrastran luego a los padres (García Pilán 2010:180-182). Elección individual, hedonismo y reflexividad ganan terreno pues a recepción irreflexiva y compromiso comunitario.

La moderna sociabilidad festiva es tradicionalizante, en tanto que su práctica crea y organiza la tradición como illusio de la comunidad festiva, pero existe exclusivamente por la suma de decisiones individuales de estar juntos, de construir y lucir las señas de una identidad a la que, por más o menos tiempo, se ha decidido ser fiel. No es una mera herencia del pasado, sino un ejercicio de autoconstrucción constante, un vehículo de la autodefinición individual. La comunidad que funda la cofradía no es preexistente ni viene impuesta desde una totalidad dada por supuesta, sino que es imaginada desde una suma de subjetividades. Estas cofradías son pues asociaciones plenamente modernas, producto de la desintegración institucional de la religión del Antiguo Régimen, y han dejado de ser esos "entes híbridos", mediadores entre alta y baja cultura, que fueron durante dicho período, porque ni siquiera reconocen ya la legitimidad de esa jerarquía.

Esto se plasma de manera especial si nos centramos en las formas de religiosidad predominantes entre los cofrades. Bien cierto es que no es difícil encontrar prácticas mágicas que beben de un pasado local: por ejemplo, las orientadas a recuperar la salud de alguien enfermo. Ahora bien, nos engañaríamos pensando que, en materia de creencias religiosas, el recurso a la tradición supone la conformidad con una norma colectiva heredada de los ancestros. La religiosidad cofrade muestra un grado de individualización que resulta inequívocamente moderno: desde esta perspectiva, no se percibe ninguna contradicción entre 
creencia e incumplimiento de los preceptos religiosos, ya que cada uno tiene derecho a construirse su propia religión: "me he hecho como todo el mundo la religión a mi manera" es una fórmula que, con variantes, se puede escuchar con frecuencia.

Esta individualiación se plasma en un deseo de autonomía que provoca que, incluso en los que se reconocen como practicantes activos (como los "capillitas" de Sevilla, que se contraponen a los "capiroteros" que sólo acuden hay fiesta -o, en términos sociológicos, los "virtuosos" de Weber, opuestos a la masa de creyentes-), reivindiquen su derecho a elegir libremente, sin dejar a la hierocracia el poder de decisión. En tal reclamación, se llega incluso a reivindicar una tradición individualizada, en la que el papel de los sacerdotes aparece claramente delimitado:

la iglesia siempre me ha tirao (...), pero siempre en el sentido de que lo que veo lógico, bajo mi punto de vista, lo comparto y lo apoyo, lo ilógico no estoy de acuerdo, ya puede decirlo el cura párroco o el arzobispo de Valencia, me da exactamente lo mismo... Si no es lógico, bajo mi punto de vista, no es lógico. Y yo pues, bajo mi tradición religiosa que tengo, yo creo en Dios pero no en los curas... ${ }^{10}$

En el mismo sentido, podemos interpretar a un cofrade de San Vicente de la Sonsierra, que afirma en una entrevista que "cada disciplinante tiene su propia causa para llevar a cabo la disciplina". ${ }^{11}$ Nadie pretende ya, como los viejos flagelantes, purgar a la comunidad dando ejemplo; ni siquiera esta práctica, pese a sus orígenes medievales, ha escapado al proceso individualizador.

Es lógico que, si se parte de la premisa de que puede haber tradiciones individualizadas, la fe adquiera un carácter fuertemente probabilista, en el que las grandes certezas han desaparecido. La religiosidad es capaz de proporcionar pautas, pero serán siempre para el comportamiento individual; programas precarios que pueden ser cambiados a voluntad o directamente desmantelados (Luckmann 1973; Berger 2016). El pluralismo moderno ha cambiado pues la relación entre clérigos y laicos; sigue existiendo, indudablemente, una interdependencia entre hierocracia y cofrades, pero el equilibrio de poder se ha

\footnotetext{
${ }^{9}$ Hermandad del Santo Silencio y Vera Cruz.

${ }^{10}$ Cofradía de Jesús en la Columna.

${ }^{11}$ Puede verse en https://www.youtube.com/watch?v=VhqDhLZ_juY
} 
desplazado drásticamente y los sacerdotes ya no son capaces de imponer los términos (siempre discutidos) de la ortodoxia.

Nos encontramos, pues, ante un horizonte de religiosidad que "tiene que ver más con preocupaciones espirituales individuales que con la conformidad a una tradición colectiva" (Lenoir 2005: 10). La búsqueda gana terreno a la observancia, y el individuo ya no está sometido a las normas del grupo; es por esto que los dirigentes de la cofradía tampoco pueden hacer nada para obligar al grueso de los cofrades a un mínimo cumplimiento de los oficios religiosos:

lo que pasa es que no puedes obligar a la hermandad... mira, cuando empiezas a decir 'tenemos que ir a tal y cual', entonces la gente ves que se va. Tienen que ir a su aire y porque ellos quieran (...). Y un año van unos y otro año van otros. ${ }^{12}$

Dentro del universo simbólico del ritual, cada uno elige libremente adherirse a sus prácticas preferidas (mayoritariamente procesiones y ejercicio de la sociabilidad), llevando a cabo un ejercicio de elección individual mediante el que construye su "religión a la carta" (Moncada 1996). No se trata de que los cofrades sean poco religiosos, ni de que las modalidades de adhesión a la norma sean múltiples: es que, en materia de creencias, ya no hay norma. El sentido está en la práctica, como afirma en una ocasión una entrevistada: "mira, yo cuando me pongo el traje ya llevo todo el sentido". ${ }^{13}$ Afirmación que dista de ser anecdótica, no solo porque la situación de liminalidad ritual viene determinada por la túnica de penitente (signo diacrítico que simboliza la inmersión en lo sagrado), sino porque no se observa ninguna necesidad de mediación hierocrática para acceder a una sacralidad que produce exclusivamente en el marco de un ritual autónomo y autorreferente. La adhesión a la tradición es pues fruto siempre de una elección, y esto vale incluso cuando se trata de azotarse la espalda desnuda para dejarla "picar" a continuación.

\footnotetext{
${ }^{12}$ Hermandad del Santo Silencio y Vera Cruz. En la procesión de Corpus de Valencia, resulta a veces difícil a la Asociación cubrir el número de personajes necesario para la misma, pese a que su número de socios lo excede en mucho.

${ }^{13}$ Hermandad del Santo Silencio y Vera Cruz.
} 


\section{DRAMATIZACIÓN RITUAL}

Afirma Giddens que la consolidación del Estado-nación y la democracia durante los siglos XIX y XX habrían disuelto la comunidad local, vaciando sus contextos locales de acción y desplazándose la verdad formular hacia la custodia de los rituales pertenecientes al ámbito de la nación (1997: 119-121). Esto nos llevaría a las religiones civiles (Bellah 2007), pero estas no quedarían fuera de nuestro ámbito: Ariño (1992) mostró, al analizar las Fallas de Valencia, cómo este ritual debe ser visto como una "liturgia civil", donde se sacraliza la identidad valenciana, afirmación que podríamos extender a otras grandes celebraciones que celebran identidades colectivas (Irazuzta 2001) que no excluyen el universo festivo de la Semana Santa (García Pilán 2011). Más matizada parece la postura, mantenida con anterioridad a Giddens, por Eisenstadt, para quien, dentro del nuevo marco estatal, había una posibilidad para el mantenimiento de identidades de determinados colectivos, donde cabía la adhesión al tradicionalismo (1972: 21-26). Efectivamente, como ha puesto de relieve Pérez-Agote (2012), la primera oleada de secularización sirve, por reacción, para reforzar determinadas prácticas religiosas: el recurso a la tradición se esgrime así como un arma contrasecularizadora. Sin embargo, con la segunda y tercera oleadas, el planteamiento debe cambiarse considerablemente, como se puede ver tanto en fiestas patronales como en Semana Santa o Corpus Christi.

Así, en Valencia, entre 1885 y 1916, las celebraciones de la Virgen de los Desamparados aparecen connotadas por una fuerte confrontación entre las fuerzas conservadoras y el anticlericalismo republicano. En medio de un ambiente sumamente tenso, la afirmación de un periodista acerca de los votos de la Virgen provoca un efecto inversamente proporcional al deseado: en 1911, una muchedumbre pugna por llevar a hombros la imagen, cuya devoción es esgrimida como una prueba de fuerza del bando católico: asistimos así al nacimiento del acto cumbre de la fiesta actual, el tumultuoso trasllat (traslado) que se celebra desde su basílica a la catedral. Entre 1916 y 1931, la evolución de la fiesta vive una acelerada fase, al encontrar el sector católico la alianza institucional del Consistorio y del asociacionismo burgués, decididos a dar un impulso turístico a la celebración. Esto implica un esfuerzo de estetización de la fiesta, pero, ante todo, que la Virgen es vinculada a una determinada manera de entender Valencia, que responde a los intereses de las clases sociales dominantes: una ideología agrarista autocomplaciente, un "regionalismo temperamental" en el que las flores y la alegre mediterraneidad juegan un papel de primer orden (Ariño 1993a: 120-133). Se aprecian pues cambios que no se pueden entender solo desde perspectivas contrasecularizadoras: la festividad de la Virgen queda 
integrada como una secuencia más de unas inequívocamente secularizadas "Fiestas de Mayo". Cambio importante, pues el objeto celebrado ya no es, únicamente la Virgen, sino que el sujeto celebrante se autocelebra al mismo tiempo que su patrona. Religiosidad católica y civil comienzan a caminar juntas.

También las procesiones de Semana Santa estuvieron ligadas durante el siglo XIX a los vaivenes políticos, llegando a carecer de continuidad en determinadas poblaciones. No obstante, durante los años veinte de la siguiente centuria, experimentan un notable impulso, dentro de un período de modernización festiva generalizada. Para entonces, miradas externas a la fiesta, como Blanco White o Castellanos de Losada, ya habían comenzado a caracterizar a diferentes poblaciones de acuerdo con sus celebraciones $\mathrm{y}$, a finales del XIX y principios del $\mathrm{XX}$, literatos como Blasco Ibáñez asocian la noción de tipismo a las mismas, concepto que se verá reforzado con el afianzamiento del fenómeno del turismo durante las primeras décadas de dicha centuria (García Pilán 2010: 91-110). Con la modernidad, la fiesta se va convirtiendo en una característica esencial a la hora de definir y autodefinir características locales, lo que indica que se hace autorreferente, autonomizándose del específico campo (religioso-católico) en el que surgió.

El franquismo supone, como ya se ha apuntado, el fin de esta ola secularizadora, pero dista de ser una mera vuelta al pasado: en sus primeras fases, ligará fascismo con tradición. La Semana Santa se resignifica profundamente, al asimilarse a Franco con la figura de Cristo, y la palingenesia de su Resurrección tras el martirio será asimilada a la de una España renacida (Rina 2017). Pero a diferencia de la articulación no conflictiva entre ritual católico y religión civil, la convivencia entre este y religión política se hace problemática: Rina (2020: 70) ha mostrado las reticencias eclesiásticas acerca de la fascistización de la Semana Santa, convertida en la fiesta por excelencia del Régimen, lo que, junto a la evolución del mismo, determinará la primacía del sector tradicionalista, donde las prácticas populares encontrarán una mejor acomodación.

La segunda oleada secularizadora que experimenta España entre los años sesenta y ochenta (Pérez-Agote 2012), alcanza a muchas festividades populares, que decaerán irremisiblemente, $y$, en algunos sitios, la Semana Santa sufrirá una importante crisis. Sin embargo, contra los pronósticos que afirmaban que la secularización acabaría con las fiestas, asistimos durante las dos últimas décadas del siglo XX, en relación con el proceso de democratización y el florecimiento de identidades locales y autonómicas, a un espectacular proceso de revitalización de rituales festivos, consistente tanto en crear fiestas ex novo como en recuperar 
"tradiciones" perdidas o en decadencia. Coincidiendo con la tercera oleada secularizadora, que implica a la vez extrañamiento y carencia de hostilidad hacia la religión (Pérez Agote 2012), mediante el ritual se crean nuevas sacralidades que desbordan por completo el ámbito eclesial, y que se articulan entre sí, compitiendo a veces y complementándose otras. Las viejas devociones locales, esas costumbres locales en común, adquieren, tradicionalizándose, matices inusitados: la Virgen del Pilar, que pasa a ser patrona de todo Aragón en 1678, se viene vinculando desde el siglo XIX al nacionalismo español; tras su utilización como símbolo nacionalcatólico, la devoción y la fiesta asisten a un proceso de folklorización y turistización, en una rápida superposición de significados que incluyen, en los últimos tiempos, la vinculación a la imagen de los triunfos alcanzados por el equipo de fútbol local (Ramón Solans 2014). No se trata de una anécdota: los triunfos deportivos del Valencia CF son también dedicados sistemáticamente a la Virgen de los Desamparados, que es la patrona de facto de la ciudad desde 1667 y de iure desde 1885, pero fue ascendida a patrona regional en 1961. Si aceptamos que el fútbol es susceptible de ser considerado una moderna religión secular (Augé 1982), vemos que los nuevos ídolos no desplazan a las viejas imágenes patronales; sino que símbolos aparentemente contrapuestos se refuerzan mutuamente (García Pilán 2020).

También se ven desplazamientos en el centro sagrado en la Semana Santa: superado el vínculo con la religión política fascista, encontramos en su seno rituales de identidad grupales, semicomunales, comunales y supracomunales (Moreno 1990), a los que puede añadirse los subgrupales, transterritoriales, extraterritoriales y virtuales (García Pilán 2011), que, sin tener ni mucho menos idéntica importancia, si prevalecen según los momentos, complejizando el espacio y el tiempo sagrado, que es sustraído en ocasiones plenamente al ámbito parroquial. Encontramos pues, en nuestros rituales festivos de matriz católica, ese "politeísmo funcional" que Beriain (2000) ha visto como característico de nuestras sociedades modernas. Del centro sagrado que suponía la religión instituida en el Antiguo Régimen, hemos pasado a un mundo que los centros sagrados son susceptibles de multiplicarse a conveniencia de los actores, complementándose en ocasiones y compitiendo en otras. Es pues el propio ritual el que consolida, pese a los continuos intentos de los clérigos de mantener un cierto control, la secularización de la sociedad, al permitir la emergencia de nuevas y múltiples sacralidades.

Es en este contexto de sacralizaciones múltiples donde se consolida lo que convenimos en llamar tradición en las sociedades destradicionalizadas. Aunque no es un fenómeno surgido de súbito, es fundamentalmente ahora cuando la 
necesidad de establecer una identidad diferenciada en una sociedad global, lleva a seleccionar, dentro del acervo cultural del pasado, las tradiciones diferenciales de cada grupo, comunidad y localidad. Así, se rescatan y reinterpretan costumbres locales, otrora comunes, y que, descontextualizadas de la sociedad que las vio nacer, solo en el ámbito del ritual adquieren sentido, convirtiéndose en nuestras tradiciones. Con la modernidad se construyen, por ejemplo, las características definitorias de cada Semana Santa: en Castilla deberá ser austera y ordenada, mientras en Andalucía será alegre y bulliciosa; Murcia se caracterizará por sus pasos escultóricos, mientras Aragón lo hará por sus tamborradas. En núcleos de población históricamente marginados, como los Poblados Marítimos de la ciudad de Valencia, las peculiaridades se buscarán en la denominación de la fiesta (Semana Santa Marinera), y en prácticas locales de hondo arraigo, como los personajes bíblicos que, pese a las prohibiciones, sobrevivieron, multiplicándose durante las últimas décadas:

la Semana Santa que hacemos aquí es muy distinta a las demás. Tenemos los personajes bíblicos que pocas Semana Santa los tienen. Los granaderos que excepto Alboraia y poco más, existen. La imaginería es muy particular. Porque aunque sea en Barcelona, hay mucho imaginario popular castellano o andaluz. Aquí no. Aquí es autóctono (...) ¿sabes? Entonces es patrimonio cultural valenciano. ${ }^{14}$

Aquí aparece un término clave, que es el patrimonio cultural, sobre el que se volverá más adelante. Pero lo que interesa es destacar cómo desde esta perspectiva podemos entender por qué otras poblaciones han optado por mantener a sus picaos o a sus empalaos: como le dijeron a Vandermeersch -quien curiosamente no parece atribuir mayor importancia a la afirmación-, "esto forma parte de nuestras tradiciones y un pueblo que olvida sus tradiciones no se cuida de su identidad y está perdido" (2004: 27). Pero esta necesidad de exhibir diferencias dentro de un ritual cuyo marco de significado teológico y doctrinal casi se ha perdido, no debe ser vista como un peso inexorable de la tradición, sino como una voluntad de ritualización de diferencias recurriendo a rasgos de diferenciación marginal (Riesman 1974: 243), que adquieren aquí una dimensión mítica, ya que son ellos los que sirven, por sí mismos, para explicar la presencia y continuidad de la tradición (García Pilán 2010).

${ }^{14}$ Hermandad de la Crucifixión del Señor. 


\section{PATRIMONIALIZACIÓN DE LA FIESTA}

En la actualidad, un total de veintidós poblaciones españolas ha recibido el reconocimiento como Fiesta de Interés Turístico Internacional para sus celebraciones de Semana Santa, mientras que tan sólo dos cuentan con dicho reconocimiento para su Corpus Christi. ${ }^{15}$ Si la Semana Santa ha llegado hasta nuestros días con una vitalidad renovada, no puede decirse lo mismo de la antigua fiesta grande del Antiguo Régimen. Inspirándonos en Alexander (2017), podríamos afirmar que el nivel de efectividad de este ritual de cara a conseguir la "refusión" de una sociedad compleja es escaso, a diferencia de las fiestas vistas anteriormente. El misterio sacramental de la transubstanciación es un concepto hoy completamente ajeno a un público para quien la compleja simbología desplegada en la procesión es completamente opaca: en Valencia, el significado de las impresionantes Roques (carros para el desfile) que desfilan en la procesión tiene que ser explicado previamente al público interesado por inequívocamente modernos grupos de voluntarios. Hay poblaciones, como Toledo o Granada, donde, por motivos identitarios, se ha elegido mantener el Corpus como fiesta mayor (Rodríguez Becerra 2006: 163-183), pero es significativo que, en Andalucía y Valencia las cofradías sacramentales hayan desaparecido en su mayor parte o se hayan visto absorbidas por las de penitencia o por las agrupaciones falleras. En ciudades como Valencia ha vivido en las últimas décadas una indudable revitalización, pero esta se vincula más a su carácter patrimonial y turístico que a sus significados doctrinales (Ariño y Gómez 2012: 61-72). Cualquier pretensión evangelizadora se ha perdido, y el control de la Iglesia se ve reducido a su obligada salida en la procesión. Del culto, pues, hemos pasado a la cultura: el gran ritual que expresaba el dogma sacramental de la Eucaristía es ahora patrimonio cultural. En consecuencia, merece ser encerrado en museos.

No sólo se trata de Corpus: la creación de museos festivos acaecida durante las últimas décadas es una parte importante dentro del proceso de más amplio alcance de patrimonialización de la cultura propio de la sociedad del riesgo (Ariño, 2000; García Pilán, 2013). Pero la propia existencia de estos certifica la muerte del contexto social en el que nació la fiesta; es decir, la sociedad tradicional: no en vano Adorno identificaba "museo" con "mausoleo" (2008: 159), mientras que Westheim lo definió como "refugio de los dioses muertos"

${ }^{15}$ Puede verificarse en https://turismo.gob.es/desarrollo-sostenibilidad/fiestas/Paginas/Fiestas-deInter\%C3\%A9s-Tur\%C3\%ADstico-Internacional.aspx 
(2006: 63). Lugar de la modernidad por excelencia, el museo es susceptible de albergar un cadáver al que todos quieren seguir viendo vivo. Esto no deja de provocar cierta perplejidad en las representaciones de algunos festeros, que no dejan de apreciar un cierto contraste entre la presencia de un museo y una fiesta cuya vitalidad, en casos como la Semana Santa, experimentan cotidianamente:

Es que lo de patrimonio parece que sea una cosa más bien muerta. Y yo creo que las fiestas nunca son una cosa muerta (...) porque la fiesta es una cosa viva, no es sólo lo que hay en el Museo. En el Museo se refleja el patrimonio, el bien cultural de la fiesta, pero nada más, la fiesta es más importante... sin eso haríamos la fiesta igual, sin lo que hay en el museo la fiesta sería igual, saldría igual, la gente participaría igual... Yo creo que es más importante ese patrimonio humano que el patrimonio cultural de la fiesta ${ }^{16}$

Institución regida por un saber experto que, por definición, puede ser cuestionado permanentemente y que se encuentra completamente al margen de la hierocracia eclesial, el museo viene a sancionar la secularización del ritual. Ello no es incompatible con la emergencia de nuevas sacralidades: en realidad, hay una traslación de significados de los objetos y los espacios de culto, hasta el punto de que en los últimos años se puede ver salir procesiones desde museos de Semana Santa, que se convierten así en nuevos templos seculares (García Pilán 2013). Como afirma Giner (2003), sacralización de lo profano y profanación de lo sagrado se acompañan de manera inextricable en la modernidad avanzada. El museo muestra, pues, que la tradición ya no está viva, pero, si se dramatiza año tras año en la calle, tampoco está muerta: transmutada en patrimonio, es un zombi de la modernidad (Hernández i Martí 2008). Visto desde esta perspectiva, el proceso de patrimonialización de la vieja religiosidad de las clases subalternas en la modernidad avanzada es claramente identificable como parte fundamental de tal esfuerzo de retradicionalización selectiva, que no es, en definitiva, otra cosa que la modernización a la carta de una tradición mediada por un proceso de secularización complejo.

\section{CONCLUSIONES}

Muchas de las que en la actualidad definimos como fiestas tradicionales se implantaron en una civilización parroquial que, conformada a partir de la

${ }^{16}$ Hermandad del Santo Cáliz. 
Contrarreforma católica, ya no existe. Los procesos de modernización que constituyen la fiesta moderna (individualización, burocratización, saber experto, patrimonialización), sancionan la retirada de lo sagrado institucionaleclesiástico. Nos encontramos, pues, ante rituales que expresan una religiosidad que trasciende por completo el marco eclesiástico, y que no cuenta con una hierocracia que la gestione. La fiesta se autonomiza de la religión (institucional), convirtiéndose en un fin en sí misma. Esta creciente autorreferencialidad, producto del proceso de secularización, sirve para crear nuevas formas de sacralidad no institucionalizadas. Pese a la ilusión de comunidad que se crea, no hay un único centro sagrado, sino una multiplicación de sacralidades a conveniencia de los actores.

La tradición ha dejado de ser raíz para convertirse en opción: dista hoy de ser ese "medio de reproducción cultural de la sociedad de carácter religioso" que fuese en el pasado (Ariño 1999: 183), para convertirse en un dispositivo legitimador del ritual, mediante el que se construye un "hilo de memoria" (Hervieu-Léger 2005), que es la fuente de una identidad sacralizada, pero inmanente y volátil. El recurso al pasado no puede servir para recuperar un mundo tan idealizado como definitivamente perdido, sino para crear una ilusión de continuidad mediante mecanismos de retradicionalización selectiva.

La religiosidad que segregan los rituales analizados está pues radicalmente alejada de las formas que tomó durante el Barroco. Se recurre a la tradición para explicar su existencia, pero nada hay en estos rituales de acción tradicional, entendida al modo weberiano (heredada, coercitiva e irreflexiva), ni de ritual integrador mediante una cosmovisión totalizante, al modo durkheimiano. La tradición moderna es eficaz precisamente porque carece de cualquier vínculo con ninguna verdad formular. Ya solo es eficaz en el marco del dispositivo simbólico que pone en marcha el ritual, que, en esta "era postcristiana" (Ariño y Gómez 2012), es susceptible de articular múltiples significados, que sólo se entienden en un marco secularizado que, a su vez, se alimenta con la práctica de la fiesta. Así como el ritual pasó de ser un sustantivo ("rito") a un adjetivo, la tradición ha pasado de ser un sustantivo a un verbo, pues, en la actualidad solo puede ser performativa: lejos de heredarse irreflexivamente, se construye y reformula continuamente en los usos que de la misma ejecutan los actores. Incapaz de estructurar nuestras vidas, se configura como una práctica de reencantamiento débil en un mundo destradicionalizado. Es posible, pues, invertir la propuesta de Mauss: no resulta exagerado afirmar que hoy la tradición es un acto ritual eficaz. 


\section{BIBLIOGRAFÍA}

ADORNO, T.W. (2008): "Museo Valéry-Proust", en Obra completa, 10/1, Madrid, Akal, pp. 159-170.

ALEXANDER, J.C. (2017): Poder y performance, Madrid, CIS.

ALONSO PONGA, J. L.; PANERO GARCÍA, P. (2008), "Gregorio Fernández en el vértice de la religiosidad popular de la Semana Santa Vallisoletana”, en Gregorio Fernández: antropología, historia y estética en el Barroco, coordinado por J.L. Alonso Ponga y P. Panero, Valladolid: Ayuntamiento, pp.23-40.

ARIAS DE SAAVEDRA, I.; LÓPEZ-GUADALUPE, M.L. (2002): La represión de la religiosidad popular. Crítica y acción contra las cofradías en la España del siglo XVIII, Granada, Universidad de Granada.

ARIAS DE SAAVEDRA, I.; LÓPEZ-GUADALUPE, M.L. (2017): "Las cofradías españolas en la Edad Moderna desde una óptica social. Tres décadas de avance historiográfico", Cuadernos de Estudios del siglo XVIII, 27, pp.11-50.

ARIÑO, A. (1988): Festes, rituals i creences, València, IAM.

ARIÑO, A. (1992): La ciudad ritual. La fiesta de las Fallas, Barcelona, Anthropos.

ARIÑO, A. (1993a): El calendari festiu a la València contemporània (1750-1936), València: IAM.

ARIÑO, A. (1993b): “La sociabilidad festera”, en Músicos y festeros valencianos, dirigido por J. Cucó, Valencia: IVAECM, pp.129-233.

ARIÑO, A. (1999): "Como lágrimas en la lluvia. El estatus de la tradición en la modernidad avanzada”, en Globalización, riesgo, reflexividad, editado por R. Ramos Torre y F. García Selgas, Madrid, CIS, pp.167-188.

ARIÑO, A. (2000): "L'invenzione del patrimonio culturale e la societè del rischio", Bollettino dell'Atlante Linguistico Italiano, III, 24, pp.9-35.

ARIÑO, A.; GÓMEZ, S. (2012): La festa mare. València, Museu Valencià d’Etnologia.

AUGÉ, M. (1982): "Football. De l'histoire sociale à l'antropologie religieuse". Le Débat, 19, pp.59-67.

BAUMAN, Z. (2003): Comunidad, Madrid, Siglo XXI.

BECK, U. (1998): La sociedad del riesgo, Barcelona, Paidós.

BELLAH, R.H. (2007): "Religión civil en América", en Las contradicciones culturales de la modernidad, editado por J. Beriain y M. Aguiluz, Barcelona, Anthropos, pp.114-138. 
BERGER, P.L. (2016): Los numerosos altares de la modernidad, Salamanca, Sígueme.

BERGER, P.L.; LUCKMANN, Th., (1997): Modernidad, pluralismo y crisis de sentido, Barcelona, Paidós.

BERIAIN, J. (2000): La lucha de los dioses en la modernidad, Barcelona, Anthropos.

BERNALES BALLESTEROS, J. (1999): “La evolución del 'paso' de misterio", en Las cofradías de Sevilla. Historia, antropología, arte, J. Sánchez Herrero et al., Sevilla, Universidad, pp.51-118.

BOISSEVAIN, J. (ed.) (1992): Revitalizing European Rituals, London, Routledge.

BOSSY, J. (1998): Dalla comunità all'individuo, Torino, Einaudi.

BOURDIEU, P. (2000): Cuestiones de sociología. Madrid: Istmo.

BURKE, P. (1996): La cultura popular en la Europa moderna, Madrid, Alianza.

CALLAHAN, W.J. (1989): Iglesia, poder y sociedad en España, 1750-1874, Madrid, Nerea.

CANDAU CHACÓN, Mạ. L. (2020): La religiosidad en la Edad Moderna, Madrid, Síntesis.

CARDINI, F. (1984): Días sagrados, Barcelona, Argos Vergara.

CHRISTIAN, W.A. (1991): Religiosidad local en la España de Felipe II, Madrid, Nerea.

COHN, N. (1985): En pos del Milenio, Madrid, Alianza.

DAILEADER, Ph. (2019): San Vicente Ferrer, su mundo y su vida, València, PUV.

DELUMEAU, J. (1989): El miedo en Occidente, Madrid, Taurus.

DURKHEIM, E. (1993): Las formas elementales de la vida religiosa, Madrid, Alianza.

EISENSTADT, S.N. (1972): "Post-Traditional Societies and the Continuity and Reconstruction of Tradition", Daedalus, 102, 1, ".1-27.

ELIAS, N. (2000): La sociedad de los individuos, Barcelona, Península.

FERNÁNDEZ BASURTE, F. (1998): La procesión de Semana Santa en la Málaga del siglo XVII, Málaga, Universidad de Málaga.

FERNÁNDEZ DE PAZ, T. (1999): "La influencia de la Contrarreforma en la configuración de la Semana Santa andaluza", en Religión y Cultura, II, coordinado por S. Rodríguez Becerra, Sevilla, Fundación Machado, pp.495-505.

GALVÁN TUDELA, J.A. (1997): La identidad herreña, Tenerife, Centro de la Cultura Popular Canaria. 
GARCÍA FERNÁNDEZ, E. (2009): "Las hermandades y cofradías de La Vera Cruz en el País Vasco”, Hispania Sacra, LXI, 124, pp.447-482.

GARCÍA PILÁN, P. (2006): "Sociabilidad festera: retradicionalización selectiva y producción de sacralidades en la modernidad avanzada", Anduli. Revista Andaluza de Ciencias Sociales, 6, pp.77-91.

GARCÍA PILÁN, P. (2010): Tradición en la modernidad avanzada: la Semana Santa Marinera de Valencia, València, Museu Valencià d'Etnologia.

GARCÍA PILÁN, P. (2011): "Rituales, descentramientos territoriales y niveles de identidad: la Semana Santa Marinera de Valencia", Revista de Dialectología y Tradiciones Populares, vol. LXVI, 2, pp.317-336.

GARCÍA PILÁN, P. (2013): "Museos festivos: de la 'religiosidad popular' al 'patrimonio cultural", El Genio Maligno, 13 (2013), pp.66- 97. Recuperado en: http://elgeniomaligno.eu/museos-festivos-de-la-\%C2\%ABreligiosidadpopular\%C2\%BB-al-\%C2\%ABpatrimonio-cultural\%C2\%BB-pedro-garcia-pilan/

GARCÍA PILÁN, P. (2020): "La Mare de Déu dels Desemparats: una devoció barroca en la València postsecular", en Mare dels Desemparats. Annex d'estudis del cicles d'exposicions, Ma T. Abad et al., València, Diputació, pp.31-35.

GIDDENS, A. (1997): "Vivir en una sociedad postradicional", en U. Beck, A. Giddens y S. Lash, Modernización reflexiva, Madrid, Alianza, pp.75-136.

GIL GIMENO, J. (2017): “Secularizaciones múltiples”, Sociología Histórica, 7, pp. 291-319. Recuperado en: https://revistas.um.es/sh/article/view/237211

GINER, S. (2003): Carisma y razón, Madrid, Alianza.

HALBWACHS, M. (2004): Los marcos sociales de la memoria. Barcelona: Anthropos.

HERNÀNDEZ I MARTÍ, G.-M. (2008): "Un zombi de la modernidad: el patrimonio cultural y sus límites", La Torre del Virrey, 5, pp.27-38.

HERVIEU-LÉGER, D. (2005): La religión, hilo de memoria, Barcelona, Herder.

HOCART, A.M. (1985): Mito, ritual y costumbre, Madrid: Siglo XXI.

IGLESIAS AUNIÓN, P. (2016): "El fenómeno de la disciplina pública. Las cofradías de 'sangre' en la Extremadura de la Edad Moderna: siglos XVI-XVIII", en XLIV Coloquios Históricos de Extremadura, Trujillo, Asociación Cultural Coloquios Históricos de Extremadura, pp. 283-307.

IRAZUZTA, I. (2001): Argentina: una construcción ritual, Bilbao, EHU.

LADERO QUESADA, M.A. (2015): Las fiestas en la Europa medieval, Madrid, Dykinson. 
LENOIR, R. (2005): Las metamorfosis de Dios, Madrid, Alianza.

LIPOVETSKY, G. (2005): El crepúsculo del deber, Barcelona, Anagrama.

LOZANO RUIZ, C.; TORREMOCHA HERNÁNDEZ, M. (2013): “Asistencia social y cofradías en el Antiguo Régimen. Historiografía, líneas de investigación y perspectivas", Chronica Nova, 30, pp.19-46.

LUCKMANN, Th. (1973): La religión invisible, Salamanca, Sígueme.

MAISONNEUVE, J. (1991): Ritos religiosos y civiles, Barcelona, Herder.

MANCHA CASTRO, J.C. (2020): La Semana Santa y la construcción simbólica del franquismo en Huelva (1937-1961), Sevilla, Universidad Internacional de Andalucía.

MANTECÓN MOVELLÁN, T.A. (1990): Contrarreforma y religiosidad popular en Cantabria. Las cofradías religiosas. Santander: Universidad de Cantabria.

MARAVALL, J.A. (2002): La cultura del Barroco, Barcelona, Ariel.

MARINAS, J.M. (2014): El poder de los santos, Madrid, La Catarata.

MAUSS, M. (1970): “La oración”, en Obras I, Barcelona, Barral, pp.93-142.

MIGUEL, A. de (2006): Los españoles y la religión, Barcelona, Debolsillo.

MONCADA, A. (1996): Religión a la carta, Madrid, Espasa.

MORENO NAVARRO, I. (1990): "Rituales colectivos de religiosidad popular y reproducción de identidades de Andalucía”, en Identidades colectivas, editado por J. Cucó y J. Pujadas, València, Generalitat Valenciana, pp.269-284.

MUIR, E. (2001): Fiesta y rito en la Europa moderna. Madrid: Editorial Complutense.

NARBONA VIZCAÍNO, R. (2017): La ciudad y la fiesta: cultura de la representación en la sociedad medieval, Madrid, Síntesis.

NAVARRO ESPINACH, G. (2014): "Las cofradías medievales en España”, Historia 396, 1, pp.107-133.

OROZCO DÍAZ, E. (2009): "La Pasión y el Barroco (consideraciones en torno a nuestra imaginería”, en Introducción al Barroco. Ensayos inéditos, Granada, Universidad, pp.209-218.

PÉREZ-AGOTE, A. (2012): Cambio religioso en España: los avatares de la secularización, Madrid, CIS.

PINGARRÓN, F. (2017): "El culto y la devoción a la Virgen de los Desamparados en la catedral de Valencia magnificados en el siglo XVIII", en La catedral ilustrada, 4, coordinado por E. Callado, València, IAM, pp.289-348. 
PO-CHIA HSIA, R. (2007): “Disciplina social y catolicismo en la Europa de los siglos XVI y XVII”, Manuscrits, 25, pp.29-43.

PRODI, P. (2017): "Europe in the Age of Reformations: The Modern State and Confessionalization", The Catholic Historical Review ,103,1, pp.1-19.

RESTIF, B. (2006): La révolution des paroisses, Rennes, Presses Universitaires de Rennes.

RICO, F.L. (2006): Misiones populares en España entre el Barroco y la Ilustración, València, Institució Alfons el Magnànim.

RIESMAN, D. (1974): Individualismo, marginalidad y cultura popular. Buenos Aires, Paidós.

RINA SIMÓN, C. (2017): "Fascismo, nacionalcatolicismo y religiosidad popular. Combates por la significación de la dictadura (1936-1940)", Historia y Política, 37, pp. 241-266.

RINA SIMÓN, C. (2020): "Cultura y ritos festivos. En torno a la legitimidad sacropopular de la dictadura”, en El franquismo en caleidoscopio, editado por Z. Box y C. Rina, Granada, Comares, pp.53-75.

RODRÍGUEZ BECERRA, S. (2006): La religión de los andaluces. Málaga: Sarriá.

RODRÍGUEZ MATEOS, J. (1989): “La disciplina pública como fenómeno penitencial barroco”, en La religiosidad popular, II, coordinado por C. Álvarez Santaló, Ma.J. Buxó y S. Rodríguez Becerra, Barcelona, Anthropos, pp.528-539.

SÁNCHEZ DE MADARIAGA, H. (1999): "Cultura religiosa y sociedad: las cofradías de laicos”, Historia Social, 35, pp.23-42.

SÁNCHEZ HERRERO, J. (1995): “El origen religioso de las cofradías de Pasión”, en La Semana Santa en Castilla y León, coordinado por M.A. Mateos, León, Junta de Castilla y León, pp.11-23.

SÁNCHEZ LORA, L. (1989): "Claves mágicas de la religiosidad barroca”, en La religiosidad popular, II, coordinado por C. Álvarez Santaló, Mạ.J. Buxó, Mà. y S. Rodríguez Becerra, Barcelona, Anthropos, pp.125-145.

SHILS, E. (1975): "Tradition", en Center and Periphery, Chicago: University of Chicago, pp.183-218.

THOMPSON, E.P. (2000): Costumbres en común, Barcelona, Crítica.

TURNER, V. (1988): El proceso ritual, Madrid, Taurus.

VANDERMEERSCH, P. (2004): Carne de la Pasión, Madrid, Trotta.

WESTHEIM, P. (2006): Arte, religión y sociedad, México, FCE. 
WEBER, M. (2002): Economía y Sociedad, México, FCE.

WILLIAMS, R. (2003): La larga revolución, Buenos Aires, Nueva Visión.

Recibido: 26 de abril de 2021

Aceptado: 19 de mayo de 2021

Pedro García Pilán es Doctor en Sociología y Licenciado en Historia por la Universitat de València. Ha sido profesor asociado de Sociología y trabaja en el Centre de Formació i Qualitat Manuel Sanchis Guarner de la Universitat de València. Sus principales líneas de investigación son la sociología del ritual, la sociología urbana y el pensamiento social de la alta modernidad. Ha coordinado los libros La sociedad valenciana en transformación (1975-2015) (con Antonio Ariño, 2018) y Tots els colors de Josep-Vicent Marqués (2018), y ha publicado los libros Tradición en la modernidad avanzada: la Semana Santa Marinera de Valencia (2010) y Mapa social de Torrent. Complexitat $i$ territori a una ciutat oberta, 2003-2005 (2007).pedro.garcia@uv.es 